\title{
Phraseology in Teaching and Learning Spanish as a Foreign Language in the USA
}

\author{
Victoria Llongo Lopez \\ ${ }^{1}$ University of Alicante, crta. San Vicente del Rapeig, s/n, 03690, Alicante, Spain \\ Brigham Young University, 84602, Provo, Utah, United States of America \\ victoriallongo@gmail.com
}

\begin{abstract}
The aim of this study is to analyze the acquisition of phraseological units at the elementary, secondary, and university levels in order to develop a better understanding of the linguistic competence of American students in learning Spanish as a foreign language in Utah. After discussing the importance of phraseology as a fundamental part of the linguistic content in the L2 classroom, we analyze the most frequent phraseological units in L2 Spanish manuals and how students in the different academic contexts where able to identify their meaning in contextualized and non-contextualized settings. The results showed the importance of context in the identification of these phraseological units with a significantly higher percentage of accuracy in the contextualized setting. The study also addresses the important role that idiomatic expressions can play in teaching phraseology and culture thus enriching the sociolinguistic competence with diatopic variation as a core of phraseology.
\end{abstract}

Keywords: Phraseology, Didactics, Diatopic variation, Spanish, Teaching.

\section{Didactics and Phraseology in Learning a Foreign Language}

The large number of studies focused on different aspects of language teaching have also touched one of the most relatively new disciplines in Linguistics called Phraseology and this has become an independent field of study, known as Phraseodidacts. Thus, within the evolution of Phraseology research this branch was considered a loophole. Nowadays, this part of the didactics of languages has been of the utmost interest for European researchers [8]. Most of them are focused on new didactic materials, different approaches, and teaching methods in order to recognize these exclusive units and their recognition by also paying particular attention to learning the meaning and linguistic communication.

Native speakers acquire phraseology as they do with vocabulary, generally by "repeating, memorizing sequences and meanings of different structures" (FormentFernández, 1998, 341). However, the Common European Framework of Reference 
for Languages reinforces not only the comprehension but also the use of most frequent familiar and everyday expressions for beginner students (A1 level). "Consequently, Phraseological units must be an integral and specific part of Teaching Plans for any foreign language (FL)" (Soslano Rodríguez, 2006).

"There is not just one tried and true "method' for teaching phraseology" (Kennedy, 2008). There are some tentatives of including distributional information from a corpus in a language learner's curriculum. This study has been divided in three different levels in education: elementary, secondary and college.

The Phraseological units selected are the ones from Repase y Escriba: curso avanzado de gramática y composición. (Maria Cantelli Dominicis. John J. Reynolds). This survey was taken by 80 elementary school students, 47 high school students and 138 university students.

This survey was divided in two parts. The first part was composed by 10 questions with phraseological units isolated where students had to choose their meaning, explain why they chose this option and say how often they heard it. The second part of the survey included 6 questions with phraseological units in context, in this case, students had to choose their meaning and the frequency of usage.

This survey took 20 minutes overall. It was presented to the students through Google Forms. In this case, we selected for ourselves the Phraseological units by importance on the manual and their inclusion in a lexical activity as parameters of frequency did not apply. These can lead to overlooking the kinds of semantic relationships associated with phraseology. As Wray \& Fitzpatrick wrote 'a learner-directed phraseology curriculum could be ideal, if it could relate the items to be learned and what the learner might be motivated to say or write'.

As Kisner (1994) and Ellis (1994) have argued, it seems that phraseology is learnt especially through implicit learning by unconsciously meeting multiword sequences repeatedly in context. The more we encounter these multiword units, the more fluent we become in retrieving and producing them (Byte \& Hopper 2001). It is almost certainly worthwhile to use explicit instruction in teaching phraseology as vocabulary. This is the most common case scenario.

\section{Phraseological unit case study}

\subsection{Elementary results}

This survey was taken by 80 students from a Spanish Dual Immersion program from Second Grade and Fifth Grade (6-8 and 10-12 years old range). All of them are native English speakers, as an anecdote, some of them recognize Spanish as their native language for being in a Dual Immersion program and speak the L2 language all the time at school. Some of them recognized speaking to a limited extent in a foreign language at home and reading books. Most of them were studying Spanish for 1-2 
years and more than 4 years. None lived in a Foreign country where the language was spoken.

According to the survey results, the phraseological units (without context) with the higher percentage of accuracy are: "Amasar una fortuna" (51.2\%). "Dar la cara por alguien" (48.8\%). "Poner los puntos sobre las íes" (46.3\%).

The idiomatic expressions with less accuracy are: "Irse a la francesa" (20\%). "Montar cachos" (31.3\%). "A caballo regalado, no se le mira el diente" (32.5\%).

The expressions in context with higher percentage of accuracy are: "Trabajar a destajo" (65\%). "Ponerse blando" (58.8\%). "Andarse con rodeos" (51.2\%).

The idiomatic expressions in context with less accuracy are: "Casa que se blanquea, inquilinos quiere" (33.8\%). "Ojos que no ven, corazón que no siente" (36.3\%). "Perro que ladra, nunca muerde" (42.5\%).

When we analyzed the results of the survey, we saw the idiomatic expressions such as "amasar una fortuna" had an equivalent in English "to amass a fortune". In this case, equivalences will be one of the most appropriate phraseological units to start with teaching in elementary schools. Followed by units like "dar la cara por alguien" or "poner los puntos sobre las íes" because they can be easily exemplified in a school context and reinforced with an image.

In this context, cultural aspects play an important role and students in elementary school know that in some European countries you greet somebody with two kisses. In this case, students identify the fact of saying 'goodbye as a French' by kissing on the cheek. It is also known that introducing vocabulary and expressions in context will help the student to understand and acquire any sequence.

\subsection{Secondary results}

This survey was taken by 47 students from different levels in high school. Most of the students (83\%) belong to $15-18$ age range and only $14.9 \%$ of the age range between $18-21$. The rest $2.1 \%$ from $12-15$ years old. In this case, we counted on more Hispanic students than elementary and college, exactly $59.6 \%$ of the students. Overall, students did not take Spanish in elementary, but they did in middle school and high school.

Most of them took 2 to 3 classes of Spanish during their education.

According to the results of the survey, secondary students achieve a higher percentage in the following phraseological units: "Dar la cara por alguien" (74.5\%). "A caballo regalado, no le mires el diente" (66\%). "No decir ni jota" and "Amasar una fortuna" $(63.8 \%)$.

The idiomatic expressions with a lower percentage of accuracy are: "Estar en el bote" (14.9\%). "Hacerle la cruz a alguien" (23.4\%). "Irse a la francesa" $(42.6 \%)$. 
The expressions in context with higher percentage of accuracy are: "Casa que se blanquea, inquilinos quiere" (63.8\%). "Trabajar a destajo" (61.7\%). "Perro que ladra, nunca muerde" (57.4\%).

The expressions in context with lower percentage of accuracy are: "Ojos que no ven, corazón que no siente" (34\%). "Ponerse blando" (48.9\%). "Andarse con rodeos" $(55.3 \%)$.

The results in high school were very interesting because there were more hispanic students. Equivalents still played an important role in unit recognition and common sequences. Nowadays in Spanish as "dar la cara for alguien" or "a caballo regalado, no le mires el diente" will be the ones we want to focus on teaching in our classrooms due to their frequency and popularity.

Some expressions as 'estar en el bote', 'hacerle la cruz a alguien' or 'irse a la francesa' are easy to perform in class or reinforce with a picture.

\subsection{University results}

In college, this survey was taken by 138 students at BYU. The two highest age ranges were students from 18-21 years old (43.4\%) and students aged from 25-30 years old $(47.8 \%)$. In this case, a minority of approximately $8 \%$ of the students are from a Spanish speaking country.

That means that a $73.2 \%$ of the students speak only English at home. The majority did not take Spanish in elementary school. Only a $32.4 \%$ had from 1-2 years in middle school and a 37\% took 3-4 years at University. At least all of these interviewed had taken one class. As cultural data, most of the students serve their missions in Spanish speaking countries, which means that they lived there at least for a couple of months in contact with the language and culture.

Phraseological expressions (without context) with higher percentage in college students are: "No decir ni jota" (92\%). "A caballo regalado, no le mires el diente" (87\%). "Poner los puntos sobre las íes" (82.6\%).

Units (without context) with less percentage of accuracy are: "Hacerle la cruz a alguien" (26.1\%). "Estar en el bote" (37\%). "Montar cachos" or "Irse a la francesa" $(56.5 \%)$.

Idiomatic expressions in context with a higher percentage of accuracy are: "Trabajar a destajo" (92.7\%). "Perro que ladra, nunca muerde" (90.6\%). "Ponerse blando" $(89.8 \%)$.

Phraseological expressions in context with a lower percentage of accuracy are: "Casa que se blanquea, inquilinos quiere" (79.7\%). "Ojos que no ven, corazón que no siente" $(83.3 \%)$. "Andarse con rodeos" $(88.3 \%)$.

In college, we can see an evolution in comprehension of the Phraseological units. The most accurate units are the hardest ones in other levels in education. Though simple 
units, much more representative and easy to perform as "hacerle la cruz a alguien", "estar en el bote" or "montar cachos" seem to be much more difficult to recognize.

\section{Diatopic variation}

This case study show us much more than how to teach idiomatic expressions, we can also take a step further to research the diatopic variation. The results of the survey show us that one of the hardest idiomatic expressions for students to recognize is 'montar cachos', which is an expression very used in Mexico. Also, the expression from the Spanish peninsula which is "irse a la francesa". Or, easily to recognize for Hispanic students in high school the South American and Central American expression "casa que se blanquea, inquilinos quiere".

Phraseology and culture are completely related. This should be an advantage for educators and learners. When assessing communication skills, the recognition and used of these native-speaker units are automatically considered as an indicator of fluency in foreign language learners. Phraseology research has specially challenged language educators to work out to maximize the exposure needed for learners to acquire phraseological units that cannot be taught explicitly. Thus, encourage students to autonomous language learning through watching movies, reading, listing to the radio, music, online, every possible way to maximize the exposure to language in use.

\begin{tabular}{|c|c|c|c|c|c|c|}
\hline PU & Answer 1 & $\%$ & Answer 2 & $\%$ & Answer 3 & $\%$ \\
\hline $\begin{array}{l}\text { 'Poner los puntos } \\
\text { sobre las íes' }\end{array}$ & $\begin{array}{l}\text { Poner los puntos en todas } \\
\text { las íes del texto. }\end{array}$ & $\begin{array}{l}38.8 \% \\
42.6 \% \\
10.9 \%\end{array}$ & $\begin{array}{l}\text { Poner las cosas claras o } \\
\text { concretar alguna } \\
\text { cuestión. }\end{array}$ & $\begin{array}{l}46.3 \% \\
46.8 \% \\
82.6 \%\end{array}$ & $\begin{array}{l}\text { Dejar de hacer algo y } \\
\text { empezar a conversar sobre } \\
\text { un tema. }\end{array}$ & $\begin{array}{l}15 \% \\
12.8 \% \\
8.7 \%\end{array}$ \\
\hline 'No decir ni jota' & No decir la verdad. & $\begin{array}{l}33.8 \% \\
25.5 \% \\
5.8 \%\end{array}$ & Hablar demasiado. & $\begin{array}{l}28.7 \% \\
10.6 \% \\
2.2 \%\end{array}$ & Permanecer en silencio. & $\begin{array}{l}37.5 \% \\
63.8 \% \\
92 \%\end{array}$ \\
\hline 'De pe a pa' & $\begin{array}{l}\text { Saber algo desde el } \\
\text { principio hasta el final. }\end{array}$ & $\begin{array}{l}42.5 \% \\
57.4 \% \\
78.3 \%\end{array}$ & $\begin{array}{l}\text { Saber algo de memoria } \\
\text { sin entenderlo. }\end{array}$ & $\begin{array}{l}33.8 \% \\
17 \% \\
5.1 \%\end{array}$ & $\begin{array}{l}\text { Saber cosas básicas y } \\
\text { esenciales. }\end{array}$ & $\begin{array}{l}23.8 \% \\
25.5 \% \\
16.7 \%\end{array}$ \\
\hline 'Irse a la francesa' & $\begin{array}{l}\text { Irse de un lugar y darle un } \\
\text { beso a todo el mundo. }\end{array}$ & $\begin{array}{l}40 \% \\
23.4 \% \\
21.7 \%\end{array}$ & $\begin{array}{l}\text { Irse de un lugar sin } \\
\text { despedirse. }\end{array}$ & $\begin{array}{l}20 \% \\
42.6 \% \\
56.5 \%\end{array}$ & $\begin{array}{l}\text { Irse de un lugar y decir un } \\
\text { adiós generalizado. }\end{array}$ & $\begin{array}{l}40 \% \\
34 \% \\
21.7 \%\end{array}$ \\
\hline
\end{tabular}




\begin{tabular}{|c|c|c|c|c|c|c|}
\hline \multirow{3}{*}{$\begin{array}{l}\text { 'A caballo regala- } \\
\text { do no se mira el } \\
\text { diente' }\end{array}$} & \multirow{2}{*}{$\begin{array}{l}\text { No me gusta el regalo que } \\
\text { me han dado pero no me }\end{array}$} & $32.5 \%$ & Me gusta el regalo que & $41.3 \%$ & El regalo es tan feo como & $28.2 \%$ \\
\hline & & $66 \%$ & tanto como a los & $21.3 \%$ & un caballo & $12.8 \%$ \\
\hline & puedo quejar. & $87 \%$ & caballos & $4.3 \%$ & con dientes amarillentos. & $8.7 \%$ \\
\hline \multirow{3}{*}{$\begin{array}{l}\text { 'Hacerle la cruz a } \\
\text { alguien' }\end{array}$} & \multirow{3}{*}{ Bendecir a alguien. } & $26.3 \%$ & \multirow{3}{*}{ Marcar a alguien } & $30 \%$ & \multirow{3}{*}{ Odiar a alguien } & $43.8 \%$ \\
\hline & & $51.1 \%$ & & $25.5 \%$ & & $23.4 \%$ \\
\hline & & $54.3 \%$ & & $19.6 \%$ & & $26.1 \%$ \\
\hline \multirow{3}{*}{ 'Estar en el bote' } & Estar a punto de obtener, & $40 \%$ & \multirow{3}{*}{$\begin{array}{l}\text { Estar a punto de atrapar } \\
\text { algo o a alguien. }\end{array}$} & $27.5 \%$ & \multirow{3}{*}{$\begin{array}{l}\text { Estar encerrado en algún } \\
\text { lugar sin acceso al exterior. }\end{array}$} & $32.5 \%$ \\
\hline & convencer o conquistar & $14.9 \%$ & & $31.9 \%$ & & $53.2 \%$ \\
\hline & algo o a alguien & $37 \%$ & & $15.9 \%$ & & $47.1 \%$ \\
\hline \multirow[t]{2}{*}{ 'Montar cachos' } & \multirow{2}{*}{$\begin{array}{l}\text { Ponerse a llorar } \\
\text { desesperadamente. }\end{array}$} & $\begin{array}{l}30 \% \\
19.1 \%\end{array}$ & \multirow{2}{*}{$\begin{array}{l}\text { Estar destrozado, con el } \\
\text { corazón partido. }\end{array}$} & $\begin{array}{l}38.8 \% \\
27.7 \%\end{array}$ & \multirow{2}{*}{$\begin{array}{l}\text { Engañar o serle infiel a } \\
\text { alguien. }\end{array}$} & $\begin{array}{l}31.3 \% \\
53.2 \%\end{array}$ \\
\hline & & $16.7 \%$ & & $26.8 \%$ & & $56.5 \%$ \\
\hline \multirow{3}{*}{$\begin{array}{l}\text { 'Amasar u } \\
\text { fortuna' }\end{array}$} & \multirow{3}{*}{ Contar mucho dinero. } & $23.8 \%$ & \multirow{3}{*}{ Producir mucho dinero. } & $51.2 \%$ & Usar el dinero que no es & $25 \%$ \\
\hline & & $17 \%$ & & $63.8 \%$ & tuyo para tu & $19.1 \%$ \\
\hline & & $10.9 \%$ & & $74.6 \%$ & propio beneficio. & $14.5 \%$ \\
\hline \multirow{3}{*}{$\begin{array}{l}\text { 'Dar la cara por } \\
\text { alguien' }\end{array}$} & \multirow{3}{*}{$\begin{array}{l}\text { Hacer el trabajo de otra } \\
\text { persona. }\end{array}$} & $33.8 \%$ & No tener vergüenza y & $17.5 \%$ & \multirow{3}{*}{$\begin{array}{l}\text { Defender o responder por } \\
\text { alguien. }\end{array}$} & $48.8 \%$ \\
\hline & & $8.5 \%$ & obtener todo & $17 \%$ & & $74.5 \%$ \\
\hline & & $9.4 \%$ & gratis. & $11.6 \%$ & & $79 \%$ \\
\hline
\end{tabular}

Table 1. Table of idiomatic expressions without context, \% of accuracy.

\begin{tabular}{|c|c|c|c|c|c|c|}
\hline PU & Answer 1 & $\%$ & Answer 2 & $\%$ & Answer 3 & $\%$ \\
\hline $\begin{array}{l}\text { Cuanto más lo pienso, más me } \\
\text { enojo. Si vuestra relación está } \\
\text { basada en la distancia, "ojos que } \\
\text { no ven, corazón que no siente", ni } \\
\text { te preocupes por lo que pase allá } \\
\text { donde sea. }\end{array}$ & $\begin{array}{l}\text { Me duele el } \\
\text { corazón y los ojos } \\
\text { de sufrimiento. }\end{array}$ & $\begin{array}{l}31.3 \% \\
25.5 \% \\
8.7 \%\end{array}$ & $\begin{array}{l}\text { No me creo lo que ven } \\
\text { mis ojos, es mentira. }\end{array}$ & $\begin{array}{l}40 \% \\
44.7 \% \\
8.7 \%\end{array}$ & $\begin{array}{l}\text { Mejor ser } \\
\text { desconocedor de } \\
\text { algo para no sufrir. }\end{array}$ & $\begin{array}{l}36.3 \% \\
34 \% \\
83.3 \%\end{array}$ \\
\hline $\begin{array}{l}\text { No me puedo creer que estén } \\
\text { sacando todos esos casos en el } \\
\text { Gobierno, al final todos los } \\
\text { políticos acabarán en la cárcel. } \\
\text { Sí, "casa que se blanquea, } \\
\text { inquilinos quiere". }\end{array}$ & $\begin{array}{l}\text { Todos los } \\
\text { políticos han } \\
\text { robado y como el } \\
\text { dinero llama al } \\
\text { dinero quieren } \\
\text { más. }\end{array}$ & $\begin{array}{l}33.8 \% \\
63.8 \% \\
79.7 \%\end{array}$ & $\begin{array}{l}\text { Todos los políticos } \\
\text { buscan nuevos } \\
\text { inquilinos para sus } \\
\text { casas. }\end{array}$ & $\begin{array}{l}38.8 \% \\
34 \% \\
11.6 \%\end{array}$ & $\begin{array}{l}\text { Todos los políticos } \\
\text { están en la cárcel } \\
\text { por blanqueo de } \\
\text { dinero y alquiler } \\
\text { de casas. }\end{array}$ & $\begin{array}{l}31.3 \% \\
8.5 \% \\
9.4 \%\end{array}$ \\
\hline
\end{tabular}




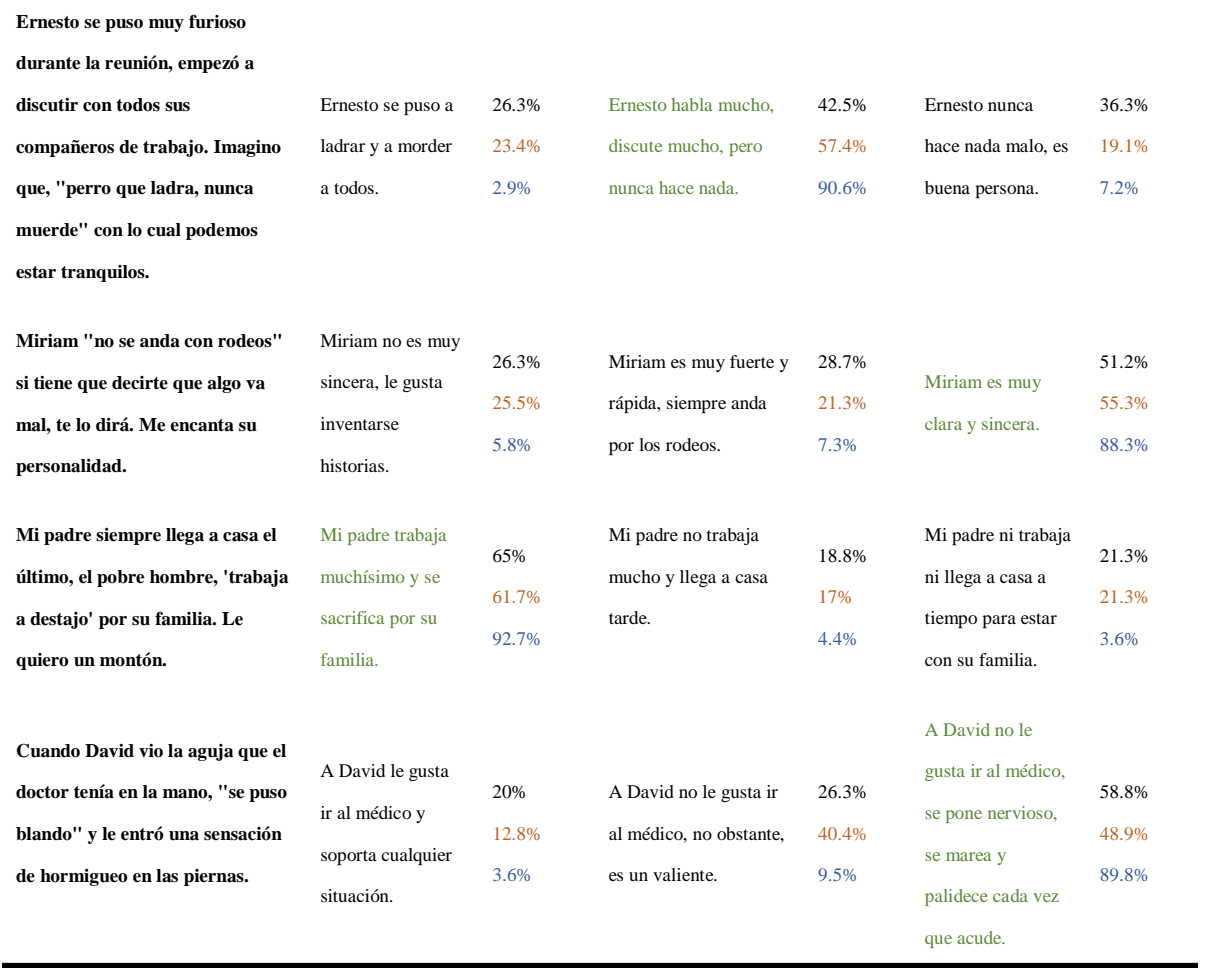

Table 2. Table of idiomatic expressions in context, \% of accuracy.

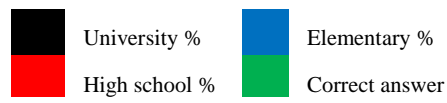

\section{Conclusion}

These results belong to an ambitious postgraduate research where more than one manual was analyzed. The student progress in learning Phraseological units in Spanish L2 was tracked and analyzed. Also, this study shows the importance of context when teaching these idiomatic expressions and the importance of helping students develop habits for forming educated guesses. Burke (1998) claims that "knowledge of slang and idiomatic expressions is fundamental to nonnative speakers' understanding of the language that native speakers actually use" (p.5).

The study also addresses the important role that idiomatic expressions can playing in teaching a foreign language and culture, thus enriching the sociolinguistic competence with diatopic variation as a core of phraseology. 


\section{References}

1. Bybee, J. 1998. The evolution of grammar. Paper prepared for the symposium Darwinianperspectives on theorigins of language. AAAS, Philadelphia.

2. Ellis, N.C., \& Sinclair, S. (in press). Working Memory in the Acquisition of Vocabulary and Syntax: Putting Language in Good Order. Quarterly Journal of Experimental Psychology. Special Issue on Working Memory.

3. Ellis, R. (1994). The Study of Second Language Acquisition. Oxford: Oxford University Press.

4. Hopper, P. \& Traugott, E. 2003. Grammaticalization. 2nd ed. Cambridge: Cambridge University. Press.

5. Forment-Fernández, M del Mar. (2001)."Hacer novillos, hacer campana o hacer la vaca: ¿qué fraseología enseñar?”, en $\mathrm{M}^{\mathrm{a}} \mathrm{A}$. Martín Zorraquino y C. Díez Pelegrín (eds.) ¿Qué Español Enseñar? Norma y Variación Lingüísticas en la Enseñanza del Español a Extranjeros. Actas del XI Congreso de la ASELE [en línea].

6. Kennedy, G.; Meunier, F; Granger, S. (2008): Phraseology in Foreign Language Learning and Teaching. In: John Benjamins.

7. Kirsner, K. (1994). Implicit processes in second language learning. In N. Ellis (Ed.), Implicit and Explicit Learning of Languages. London: Academic Press.

8. Kühn (1987), Larger (1997), Ettinger (1998), González-Rey (2012), Corpas Pastor (1996), Penadés Martinez (1999), Ruiz Gurillo (2000), Mugrón Huerta (2015), among others.

9. Luna, C.J and Ortiz Rodríguez, C.: La semántica cognitiva en la enseñanzaaprendizaje de las unidades fraseológicas en ELE: el ejemplo de los somatismos. In: Universidad Autónoma de Barcelona).

10. Nuñez-Román, F.: Enseñar fraseología: consideraciones sobre la fraseodidáctica del español. In: Universidad de Sevilla.

11. Solano-Rodríguez, C. (1993): "Las unidades fraseologícas del francés y del español: tipología y clasificación". In: Paremia, 21. 117-128.

12. Wray, A \& Fitzpatrick, T (2008). Why can't you just leave it alone? Deviations from memorized language as a gauge of nativelike competence... In Meunier, F. \& Granger, S. (eds.) Phraseology in Foreign Language Learning and Teaching. Amsterdam: John Benjamins. 